\title{
Studi Kelayakan dengan Mempertimbangkan Aspek Finansial dan Sensitivitas pada Rencana Investasi Penambangan Batu Kapur di PT. ANZ Sumatera Selatan
}

\author{
Ceni Febi Kurnia Sari \\ Program Studi Teknik Pertambangan, Universitas Papua - Manokwari \\ Jl. Gunung Salju, Amban - Manokwari - Papua Barat \\ Email: ceniey15@gmail.com
}

\begin{abstract}
ABSTRAK
Dalam suatu studi kelayakan pada rencana investasi proyek penambangan, pendapat teknikal dan informasi tentang parameter yang berhubungan dengan desain, metode ekstraksi, biaya produksi, recovery dan laju penambangan serta informasi tentang variabel lainnya akan berguna bila dilengkapi dengan analisis finansial. Hal ini disebabkan karena studi kelayakan tambang adalah suatu proses interative antar variabel utamanya, yang terdiri dari cadangan (reserves), skala tambang (mine size) dan biaya produksi (cost production). Sebagai bagian dari studi kelayakan penambangan batu kapur di PT. ANZ - Sumatera Selatan ini, analisis finansial dilakukan untuk melengkapi kajian teknis yang telah dilakukan sebelumnya. Analisis finansial ini dilakukan berdasarkan konsep Discounted Cash Flow Analysis. Sebagai dasar analisis, komponen-komponen modal dan biaya produksi digunakan sebagai masukan utama. Analisis ini dilakukan berdasarkan pola kerja yang ditetapkan untuk melakukan penambangan, yaitu: operasi penambangan sebagian dilakukan sendiri, namun alat penambangan utama dan pengangkutan serta alat-alat pendukung seluruhnya milik sendiri. Studi kelayakan ini berdasarkan umur tambang selama 20 tahun serta sebagai bagian dari studi kelayakan tambang batu kapur dilakukan analisis finansial dengan tujuan untuk melengkapi kajian teknis yang telah dilakukan sebelumnya. Dari analisis finansial ini barulah dapat dibuat analisis sensitivitas yang bertujuan untuk mengkaji sejauh mana perubahan parameter dalam aspek finansial berpengaruh terhadap keputusan yang akan dipilih.
\end{abstract}

Kata kunci: Studi Kelayakan, Penambangan, Batu Kapur, Analisis Finansial dan Analisis Sensitivitas.

\begin{abstract}
In a feasibility study on mining project investment plans, professional opinions and information about design-related parameters, extraction methods, production costs, recovery and mining rate, as well as information about variables, will be useful when equipped with financial analysis. The mine feasibility study is an interative process between its main variables, consisting of reserves, mine size and cost production (costs). As part of the feasibility study of limestone mining at PT. ANZ-South Sumatera, financial analysis is conducted to complete the technical studies that do before. This


economic analysis based on the concept of Discounted Cash Flow Analysis. As the basis of the review, the components of capital and production costs use as primary inputs. This analysis is conducted based on the work patterns set to perform mining, namely: the mining operations are partly done by themselves, but the main mining tools and transportation and supporting tools are entirely proprietary. This feasibility study based on 20 years of my life and as part of a limestone mine feasibility study carried out financial analysis intending to complete the technical studies previously conducted. From this financial analysis can then be created a sensitivity analysis that aims to assess the extent of the parameter changes in financial aspects affects the decision to be chosen.

Keywords: Feasibility Study, Mining, Limestone, Financial Analysis, Sensitivity Analysis.

\section{Pendahuluan}

Memasuki era globalisasi dan era industri 4.0 ini, pembangunan tetap gencar dilakukan oleh pemerintah, baik pembangunan infrastruktur dan sarana penunjang lainnya guna meningkatkan pertumbuhan di sektor ekonomi negara. Salah satu perusahaan yang bergerak untuk menunjang pertumbuhan ekonomi ini adalah PT.ANZ. PT. ANZ ini secara administrasi terletak di Kabupaten Ogan Komering Ulu terletak antara 103 40' sampai dengan 104 33' Bujur Timur dan antara 3 45' sampai dengan 4 55' Lintang Selatan. Kabupaten Ogan Komering Ulu terdiri dari 13 Kecamatan. Lokasi IUP Eksplorasi PT. ANZ termasuk ke dalam Kecamatan Baturaja Barat.

Lokasi IUP Eksplorasi PT. ANZ terdapat di Kecamatan Baturaja Barat. Dimana secara sektoral PT. ANZ ini salah satu kegiatannya adalah melaksanakan usaha pertambangan sebagai penyedia batu kapur yang sebagai bahan baku untuk semen ini dituntut agar bisa memberikan kontribusi yang sebesar-besarnya terhadap perekonomian nasional. Salah satu upaya untuk dapat memberikan kontribusi terhadap perekonomian ini maka PT. ANZ haruslah melakukan studi kelayakan sebelum melakukan kegiatan eksplorasi penambangan batu gamping, agar perusahaan bisa mengetahui layak atau tidaknya investasi penambangan batu kapur ini dilakukan. Beberapa metode dan asumsi yang digunakan dalam menganalisa aspek keuangan dan keekonomian PT. ANZ adalah:

a. Komposisi ekuitas adalah $100 \%$ modal sendiri;

b. Faktor eskalasi yang digunakan 1,5\% pertahun untuk komponen biaya produksi dan $1 \%$ untuk pendapatan;

c. Metode perhitungan Depresiasi dan Amortisasi adalah linier (garis lurus) dengan mengabaikan pendapatan dari nilai sisa.

Parameter yang akan digunakan dalam melakukan analisis keekonomian dalam rencana investasi proyek penambangan batu kapur PT. ANZ adalah: menentukan parameter dasar, yakni kajian teknis penambangan batu kapur

UNITEX Vol 12 No.2 Juli-Desember 2019

p-ISSN 2089-3957 | e-ISSN 2580-2585 
menghasilkan parameter dasar yang melandasi perhitungan nilai-nilai investasi dari proyek tersebut, seperti; jumlah sumberdaya batu kapur, kapasitas produksi batu kapur, jenis dan jumlah peralatan operasi penambangan, jenis dan jumlah peralatan pendukung, infrastruktur dalam dan luar tambang, segmen pasar batu kapur, harga jual batu kapur, menghitung proyeksi pendapatan (Revenue), perhitungan proyeksi pendapatan (revenue) merupakan perkiraan dana yang masuk atau diterima oleh PT. ANZ sebagai hasil penjualan produksi batu kapur yang dihasilkan sesuai dengan skenario produksi dan harga batu kapur yang direncanakan, menghitung Ongkos Produksi (Production Cost) yaitu perhitungan ongkos produksi (production cost) adalah perkiraan dana yang dikeluarkan PT. ANZ sebagai akibat dari kegiatan operasi untuk menghasilkan produk batu kapur bersih yang siap dijual ke pasar, menghitung biaya investasi meliputi dana yang dikeluarkan PT. ANZ sebagai akibat realisasi kegiatan dalam masa pra penambangan yang mencakup kegiatan studi eksplorasi, studi kelayakan, studi AMDAL, biaya persiapan pengembangan daerah (development), biaya konstruksi infrastruktur baru, pembelian atau pengadaan peralatan sampai kegiatan proyek penambangan batu kapur siap dilakukan, membuat model cash flow dilakukan untuk mengkaji kelayakan finansial investasi proyek penambangan batu kapur dengan model aliran kas (cash-flow) proyek selama produksi penambangan selama 20 tahun.

Aliran kas dikelompokkan menjadi aliran kas pada titik awal proyek, selama tahap operasional dan pada tahap akhir proyek. Dalam perhitungan aliran kas ini juga memasukkan faktor perhitungan depresiasi, amortisasi, pengembalian cicilan pokok dan bunga pinjaman dana investasi serta faktor eskalasi serta menghitung depresiasi dan amortisasi dimana depresiasi dan amortisasi bukanlah pengeluaran kas tetapi suatu metode perhitungan akuntansi yang bermaksud membebankan biaya perolehan asset berwujud dan asset tidak berwujud dengan mendistribusikan selama periode tertentu, dimana asset tersebut masih berfungsi. Menurut peraturan, depresiasi dan amortisasi dianggap sebagi suatu pengeluaran yang dapat dipotong dari bagian yang akan dikenakan pajak. Untuk itu, maka perlu diupayakan untuk mendepresiasikan asset dalam periode sesingkat mungkin dalam batas-batas periode sesingkat mungkin dan diizinkan oleh peraturan yang ada. Dengan upaya itu, maka diharapkan akan mengurangi jumlah pajak yang harus dibayar pada tahun-tahun awal operasi, sehingga dapat meningkatkan aliran kas masuk dan mempercepat pengembalian (recovery) biaya perolehan asset. Harapannya adalah dengan mengetahui studi kelayakan investasi penambangan batu kapur perusahaan PT. ANZ - Sumatera Selatan ini dapat diajadikan masukan bagi perusahaan sendiri dan pihak pemerintah agar bisa dikelola dengan lebih cermat dan baik ke depannya.

\section{Metode Penelitian}

Metode penelitian adalah metode penelitian survei dan pemetaan, dimana metode survei dengan teknik pengambilan sampel terhadap responden dengan teknik pengambilan sampel yang menggunakan teknik purposive sampling. Teknik 
pengambilan sampel yang digunakan dalam penelitian ini adalah teknik pengambilan sampel dengan menggunakan teknik purposive sampling, yang artinya sampel diambil secara acak oleh peneliti dari populasi yang ada. Untuk responden kunci diambil secara purposive, yang artinya responden ditentukan oleh peneliti.

Metode pemetaan ini melakukan pemetaan terhadap topografi dengan skala yang menyesuaikan pada kondisi di lapangan yang sesungguhnya, mengacu pada skala 1 : 25.000 .

\section{Hasil dan Pembahasan}

\section{Modal Tetap}

Perhitungan biaya investasi modal tetap adalah perkiraan dana yang dikeluarkan sebagai akibat realisasi kegiatan pra-penambangan yang mencakup pengurusan izin, kegiatan eksplorasi, penyusunan dokumen teknis, biaya konstruksi infrastruktur, pembelian perlengkapan sampai kegiatan proyek penambangan siap dilakukan. Untuk memudahkan perhitungan biaya investasi modal tetap dikelompokkan menjadi:

a. Biaya investasi awal (tahap pendahuluan), yang terdiri dari: biaya perizinan dan kegiatan eksplorasi, biaya penyusunan dokumen-dokumen teknis (studi kelayakan dan AMDAL;

b. Biaya investasi pembebasan lahan yang terdiri dari: biaya pembebasan lahan tambang, stockpile, dan kolam pengendapan, biaya pembebasan lahan jalan tambang, biaya pembebasan lahan kantor, workshop, dan sarana pendukung lainnya;

c. Biaya investasi infrastruktur tambang, terdiri dari: biaya pembangunan fasilitas tambang Biaya pembangunan fasilitas pengolahan biaya pembangunan fasilitas penunjang;

d. Biaya investasi/pembelian perlengkapan, yaitu: investasi perlengkapan K3.

Berdasarkan analisis yang dilakukan maka diketahui bahwa investasi modal tetap keseluruhan yang dibutuhkan untuk proyek penambangan pada tahun pertama sebesar Rp. 40.055.800.000,-. Investasi modal tetap dapat diuraikan sebagai berikut:

\section{Investasi Perizinan}

Investasi perizinan berupa pengurusan perizinan, biaya eksplorasi, biaya studi kelayakan dan biaya UKL - UPL dimana Nilai prakiraan investasi perizinan adalah sebesar Rp. $\mathbf{2 . 5 0 0 . 0 0 0 . 0 0 0 , - - ~}$

\section{Pembebasan Lahan}

Perhitungan biaya pembebasan lahan diasumsikan seluruhnya dilakukan di depan (pada tahun ke-0), mengabaikan pertimbangan jadwal penambangan dan jadwal rencana produksi (umur tambang). Berdasarkan pertimbangan diatas, maka nilai prakiraan investasi yang dikeluarkan pada tahap pembebasan lahan adalah sebesar Rp. 4.400.000.000,- dimana 
pembebasan lahan dilakukan secara bertahap selama 10 tahun dengan anggaran pertahun Rp. 440.000.000,-.

\section{Investasi Pembangunan Sarana dan Prasarana}

Investasi Pembangunan Sarana dan Prasarana Tambang batu kapur ini meliputi: investasi jalan angkut, investasi pembuatan mess dan karyawan, investasi pembuatan sarana air bersih, investasi sarana utility. Nilai perkiraan investasi pembangunan sarana dan prasarana adalah sebesar $\mathbf{R p .}$ $3.850 .000 .000,-$.

\section{Investasi/Pembelian Peralatan Utama dan Peralatan Penunjang}

Perhitungan biaya ini didasarkan pada beberapa pertimbangan, antara lain; daftar kebutuhan peralatan (jumlah, spesifikasi teknis dan waktu) disesuaikan dengan jadwal produksi batu kapur Jadwal pembelian peralatan sesuai kebutuhan dengan mempertimbangkan umur alat masing-masing. Jadwal penggunaan anggaran untuk pembelian peralatan berdasarkan harga perolehan Total Investasi/pembelian peralatan utama maupun peralatan penunjang pada tahun pertama adalah $\mathbf{R p}$. 27.225.000.000,-.

5. Investasi Peralatan Teknik dan Manajemen

Adapun Total Investasi/Peralatan Teknik dan Manajemen pada tahun pertama adalah Rp. 1.771.800.000,-.

\section{Modal Kerja}

Biaya modal kerja adalah biaya yang harus disediakan untuk memenuhi biaya produksi penambangan, sampai dengan masa perusahaan bisa memperoleh pendapatan dari hasil penjualan, sehingga dari pendapatan penjualan tersebut perusahaan mampu membiayai produksinya sendiri. Adapun besarnya modal kerja tahun pertama adalah Rp. 4.269.000.000,-.

\section{Sumber Dana}

Jenis sumber dana untuk proyek penambangan adalah dengan menggunakan modal sendiri dimana perusahaan pengeluaran dana untuk modal sendiri di tahun awal sebesar Rp. 40.055.800.000,--

\section{Biaya Produksi}

Biaya Produksi (Production Cost) merupakan besarnya dana yang harus dikeluarkan untuk membiayai semua kegiatan produksi penambangan hingga siap dan sampai untuk dijual. Biaya produksi ini mencakup biaya produksi langsung dan biaya produksi tidak langsung. Biaya produksi langsung operasi penambangan, terdiri dari: biaya pengupasan tanah penutup, biaya penambangan, biaya pengolahan, biaya pengangkutan, biaya peralatan pendukung tambang dan biaya stockpile. 
Biaya produksi tak langsung operasi penambangan, terdiri dari: biaya tenaga kerja, biaya pengelolaan dan pemantauan lingkungan, biaya reklamasi dan pasca tambang dan CSR Development.

Berdasarkan Perhitungan diketahui Biaya Operasional Penambangan, biaya produksi langsung tahun pertama adalah Rp. 19.558.020.000,- atau Rp. 65.193/m³ . Dan Total Biaya Operasional Produksi Tak Langsung tahun pertama adalah Rp.1.044.164.655,- atau Rp. 3.481, $/ \mathrm{m}^{3}$. Untuk menghitung biaya operasi penambangan pada satu periode produksi, maka beberapa aspek yang menjadi pertimbangan, adalah: Target produksi yang direncanakan, Peralatan utama penambangan yang dioperasikan, Peralatan pendukung penambangan serta Sumber Daya Manusia untuk melakukan Operasional Penambangan. Berdasarkan perhitungan diketahui bahwa biaya produksi pada proyek penambangan di tahun pertama adalah Rp. 20.602.184.655 atau Rp. 68.674,-//m³ batu kapur.

\section{Biaya Umum dan Administrasi}

Biaya umum dan administrasi adalah besarnya dana yang harus dikeluarkan untuk membiayai semua kegiatan diluar operasi produksi. Biaya umum dan administrasi ini mencakup biaya untuk penyelenggaraan kegiatan- kegiatan: administrasi kantor tambang, administrasi personel (gaji, asuransi, perjalanan dinas, makan), administrasi pemeliharaan infrastruktur dan administrasi pemasaran. Biaya umum dan administrasi pada proyek penambangan pada tahun pertama adalah Rp. 4.070.901.000,-.

\section{Depresiasi dan Amortisasi}

Depresiasi dan amortisasi bukanlah pengeluaran kas, tetapi suatu metode perhitungan akutansi yang bermaksud membebankan biaya perolehan aktiva tetap atau aset berwujud dan asset tidak berwujud, dengan menyebar selama periode tertentu, dimana aset tersebut masih berfungsi. Dalam menghitung depresiasi digunakan beberapa pendekatan: Metode depresiasi yang ada dipilih metode depresiasi garis lurus (straight line depreciation), yang melakukan depresiasi merata sepanjang periode aset masih berfungsi; Basis atau biaya pertama yang digunakan sebagai dasar depresiasi adalah harga perolehan ditambah biaya pengangkutan dan pemasangan alat sampai siap pakai; Periode recovery atau umur depresiasi dari alat yang didepresiasikan, bervariasi tergantung dari jenis alat; Sampai dengan akhir umur alat, setiap aset didepresiasikan sebesar $75 \%$.Berdasarkan hal tersebut, maka besarnya depresiasi dan amortisasi selama masa produksi tahun pertama adalah Rp. 714.680.000,-.

\section{Pendapatan Perusahaan}

Dalam analisis ini, hasil produksi diasumsikan akan dijual sampai di pabrik PT. Semen Baturaja seharga Rp. 120.000,- per $\mathbf{m}^{3}$. Berdasarkan rencana UNITEX Vol 12 No.2 Juli-Desember 2019 p-ISSN 2089-3957 | e-ISSN 2580-2585 
penjualan rata-rata sebesar $300.000 \mathrm{~m} 3 /$ tahun di tahun 1 , maka dapat diproyeksikan penerimaan penjualan di tahun pertama adalah sebesar $\mathbf{R} \mathbf{p}$. $36.000 .000 .000,-\cdot$

\section{Laporan Keuangan Perusahaan}

Selama umur investasi proyek penambangan, akan terjadi aliran kas masuk (cash inflow) dan aliran kas keluar (cash outflow). Besarnya aliran kas masuk ini sangat ditentukan oleh beberapa faktor dibawah ini: Laba bersih yang diterima perusahaan baik untung atau rugi. Penanaman modal sendiri untuk investasi dari pihak perusahaan (100\%) Sedangkan laba bersih yang diterima perusahaan merupakan fungsi dari pendapatan yang diterima dengan biaya yang harus dikeluarkan. Selisih antara pendapatan dan biaya tersebut merupakan laba bagi perusahaan.

\section{Studi Kelayakan}

Kriteria penilaian finansial dalam studi kelayakan merupakan alat bantu bagi manajemen untuk dijadikan pembanding antara berbagai pilihan alternatif investasi yang akan dilakukan. Ada beberapa kriteria finansial yang dianggap baku diantaranya, Nilai Sekarang Bersih (Net Present value/NPV), Tingkat Pengembalian Modal (Internal Rate Of Return/IRR), sedangkan kriteria yang tidak menggunakan konsep ekuivalen yang digunakan adalah Metode Periode Pengembalian Modal (Pay Back Period/PBP).

\section{Perhitungan "Net Present Value" (NPV)}

Konsep Nilai Sekarang Bersih (Net Present Value) didasarkan pada konsep mendiskonto seluruh aliran kas (cashflow) ke nilai sekarang (present value). Dengan mendiskontokan semua aliran kas masuk (cash inflow) dan aliran kas keluar (cash outflow) selama umur proyek ke nilai sekarang, kemudian menghitungnya memakai harga saat ini. Dengan demikian, penilaian NPV memperhatikan dua hal sekaligus, yaitu faktor nilai waktu dari uang dan selisih besarnya aliran kas masuk dan keluar. Dengan kata lain NPV dapat menunjukkan jumlah (lumpsum) dengan arus diskonto (discounted) tertentu dan memberikan berapa besarnya uang pada saat ini. Dengan menggunakan kriteria penilaian NPV dalam analisis finansial ini akan diperoleh beberapa kelebihan, yaitu: telah memasukkan faktor nilai waktu dari uang, telah mempertimbangkan semua aspek aliran kas proyek. Berdasarkan hasil perhitungan tersebut diperoleh besaran NPV 20\% pada rencana proyek penambangan adalah sebesar Rp. 17.173.238.047-atau bernilai positif.

\section{Perhitungan Internal Rate of Return (IRR)}

Perhitungan IRR merupakan perhitungan laju pengembalian yang menghasilkan. NPV aliran kas masuk sama dengan aliran kas keluar. Pada metode NPV, 
analisis dilakukan dengan menentukan terlebih dahulu besarnya laju pengembalian (discounted). Besarnya IRR yang dicari adalah yang memberikan kondisi NPV $=0$ (nol). Dalam menganalisis investasi dengan IRR ditentukan sebagai berikut:

IRR > i yang diinginkan, maka proyek investasi diterima.

IRR < i yang diinginkan, maka proyek investasi ditolak.

Nilai laju pengembalian internal memberikan gambaran bahwa usulan investasi proyek penambangan lebih menarik untuk dilakukan bila dibandingkan dengan kegiatan menyimpan modal di bank dengan laju pengembalian yang lebih kecil. Artinya menanam modal investasi di proyek penambangan lebih menguntungkan bila dibandingkan dengan menanam modal di bank. Berdasarkan perhitungan yang telah dilakukan, laju pengembalian internal (IRR) pada proyek penambangan adalah sebesar $\mathbf{2 7 . 8 0} \%$ atau lebih besar dari bunga minimal bank yaitu $\mathbf{1 4 \%}$.

\section{Perhitungan Waktu Pengembalian Modal (Pay Back Period/PBP)}

Pay Back Period (PBP) menunjukkan periode waktu yang digunakan untuk menutup kembali modal yang telah diinvestasikan dengan hasil yang akan diperoleh dari aliran kas bersih dari investasi tersebut. Proyek dianggap menguntungkan apabila PBP lebih dahulu tercapai dari umur tambang. Berdasarkan hasil perhitungan didapatkan PBP untuk proyek penambangan adalah selama 3 tahun 1 bulan 12 hari sejak dimulainya kegiatan penambangan.

\section{Analisis Sensitivitas dengan Parameter Biaya Produksi}

Pada parameter biaya produksi akan dilakukan perubahan nilai secara variasi dengan cara memberikan nilai yang semakin meningkat (naik). Pada setiap kenaikan nilai biaya produksi akan dilakukan perhitungan kembali kriteria penilaian finansial seperti (NPV, IRR, Payback Period) dan hasilnya akan dijadikan dasar untuk mengevaluasi tingkat sensitivitas dari penilaian kelayakan. Pada saat kenaikan biaya produksi dinilai sudah cukup sensitif terhadap keputusan penilaian kelayakan, maka pemberian harga kenaikan dihentikan.

Berdasarkan hasil-hasil perhitungan analisis kepekaan yang telah dilakukan dengan variasi yang dibuat seperti di atas, maka rencana investasi untuk proyek penambangan yang akan dilakukan dapat disimpulkan sebagai berikut:

Rencana investasi proyek masih dinilai layak untuk kenaikan biaya produksi sampai dengan $10 \%$ dengan $\mathrm{IRR}=22,13 \% \mathrm{PBP}=4.22$ tahun, $\mathrm{NPV}=\mathrm{Rp}$. 4.566.972.274,- Rencana investasi proyek masih dinilai layak untuk penurunan harga jual batu kapur sampai dengan $10 \%$ dengan $\mathrm{IRR}=16,36 \%, \mathrm{PBP}=6,32$ tahun, NPV $=$ Rp. 860.008.240,- Variabel kenaikan biaya produksi dan variabel penurunan harga jual batu kapur sama-sama peka terhadap rencana investasi proyek. 
Tabel 1. Pengaruh kenaikan biaya produksi terhadap NPV, IRR, dan payback period

\begin{tabular}{|c|c|c|c|}
\hline $\begin{array}{c}\text { Kenaikan } \\
\text { Biaya Produksi }\end{array}$ & NPV (Rp) & IRR (\%) & $\begin{array}{c}\text { Payback Period } \\
\text { (Tahun) }\end{array}$ \\
\hline $1,0 \%$ & 15.912 .611 .470 & 26,48 & 3,04 \\
\hline $5,0 \%$ & 10.870 .105 .161 & 24,77 & 4,43 \\
\hline $10 \%$ & 4.566 .972 .274 & 22,13 & 4,22 \\
\hline
\end{tabular}

Tabel 2. Pengaruh penurunan harga jual batu kapur terhadap NPV, IRR, dan payback period

\begin{tabular}{|c|c|l|l|}
\hline $\begin{array}{c}\text { Penurunan } \\
\text { Harga Jual Batu } \\
\text { kapur }\end{array}$ & $\begin{array}{c}\text { NPV } \\
\text { (Rp) }\end{array}$ & IRR (\%) & PBP (Tahun) \\
\hline $1,0 \%$ & $28.381 .253,843$ & 26,10 & 4,03 \\
\hline $5,0 \%$ & 16.149 .589 .131 & 22,26 & 4,25 \\
\hline $10 \%$ & 860.008 .240 & 16,36 & 6,32 \\
\hline
\end{tabular}

\section{Simpulan}

Berdasarkan analisis aliran finansial dan analisis sensitivitas yang telah dilakukan, dapat disimpulkan bahwa proyek penambangan batu kapur ini secara ekonomi dinilai layak. Hal ini dapat terlihat dari besarnya nilai IRR yang lebih besar dari discounted factor yang menunjukkan bahwa kegiatan penambangan ini dapat mendapatkan keuntungan sebesar 27,80\% dari margin biaya keseluruhan kegiatan penambangan. Selain itu, nilai payback period sebesar 3 tahun 1 bulan 12 hari juga menunjukkan bahwa kegiatan penambangan ini, modalnya akan kembali pada tahun ke-2 pada kegiatan penambangan.

\section{Daftar Pustaka}

Arif, I. (2008). Analisis Investasi Tambang. ITB. Bandung.

Djajadiningrat. (2007). Pertambangan Lingkungan dan Kesejahteraan Masyarakat, (Makalah Seminar Ilmiah Nasional Mining, Environment and People Welfare), Manado, Universitas Sam Ratulangi.

Musfiqon. (2012). Panduan Lengkap Metodologi Penelitian Pendidikan. Jakarta: Prestasi Pustakarya.

Prodjosumarto, P. (2000). Tambang Terbuka. ITB. Bandung. 
Sari, C. F. K. (2005). Analisis Keterkaitan Industri Semen PT. Indocement Tunggal Prakarsa, Tbk Terhadap Sosial Ekonomi Daerah di Kabupaten Cirebon (Studi Kasus: PT. ITP, Tbk - Palimanan), Tesis tidak diterbitkan, Bandung.

Siswanto, S. (1986). Studi Kelayakan Proyek. Pusaka Binaan Pressindo. Jakarta.

Sumatera Selatan dalam Angka. (2017). BPS.

Umar, H. (2001). Studi Kelayakan Bisnis. Jakarta: PT. Gramedia Pustaka Utama. 